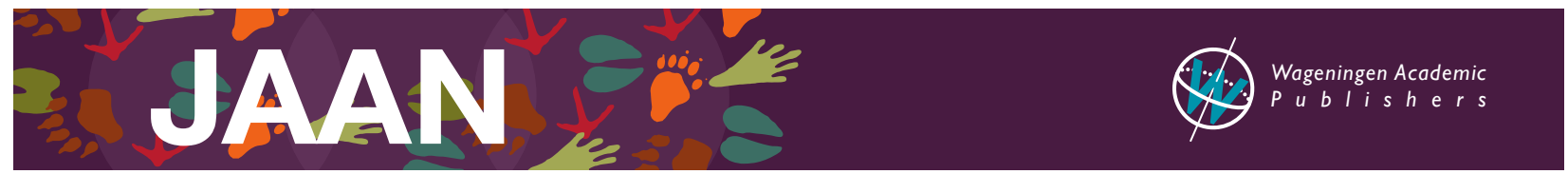

\title{
Global survey of limestone used in poultry diets: calcium content, particle size and solubility
}

\author{
S. Gilani ${ }^{1 *}$, A. Mereu ${ }^{1}$, W. Li ${ }^{1}$, P.W. Plumstead ${ }^{2}$, R. Angel ${ }^{3}$, G. Wilks ${ }^{2}$ and Y. Dersjant-Li ${ }^{1}$ \\ ${ }^{1}$ Danisco Animal Nutrition and Health (IFF), Willem Einthovenstraat 4, 2342 BH Oegstgeest, the Netherlands; ${ }^{2}$ Chemuniqué \\ (Pty) Ltd, Lanseria Business Park, 28 Eagle Lane, 1739 Lanseria, South Africa; ${ }^{3}$ Department of Animal and Avian Sciences, \\ University of Maryland, College Park, MD 20742, USA; saad.gilani@iff.com
}

Received: 25 October 2021 / Accepted: 18 January 2022

() 2022 S. Gilani

RESEARCH ARTICLE

POULTRY

\begin{abstract}
Limestone is used in poultry diets as a calcium $(\mathrm{Ca})$ source. Feed formulation is often based on an estimate of limestone Ca content or, less frequently, wet chemistry analysis. However, limestone composition may vary, which has not previously been studied on a large scale. In this study, 641 limestone samples supplied to poultry feed mills in 40 countries across eight global regions were collected and analysed for macro- and micromineral content, particle size (geometric mean diameter, GMD), and in vitro solubility. Mean Ca content of fine limestone $(\mathrm{GMD}<1000 \mu \mathrm{m}, \mathrm{n}=566)$ was $37.8 \%$ (range 33.3-39.7\%) and for coarse limestone (GMD $>1000 \mu \mathrm{m}, \mathrm{n}=75$ ) was $38.0 \%$ (range 34.7-40.0\%). There was marked variation among and within regions in the concentration of other macro minerals and microminerals. Particle size (GMD) of fine limestone was $288 \mu \mathrm{m}$ (range 37.7-991.9 $\mu \mathrm{m}$ ) and $1,689 \mathrm{~mm}$ for coarse limestone (range 301.6-3,067.9 $\mu \mathrm{m}$ ). In vitro solubility of fine limestone (5 min incubation, $\mathrm{pH}=3.0$ ) was $68.4 \%$ (range 18.8 to $99.4 \%$ ). Particle size only explained $52 \%$ of the variation in 5 min incubation solubility $\left(\mathrm{R}^{2}=0.52\right)$. For coarse limestone, mean solubility (30 min incubation) was $65.5 \%$ (range $23.2-96 \%$ ) which was not correlated $\left(R^{2}=0.09\right)$ with particle size. Particle size and solubility rate of limestone have been shown to alter $\mathrm{Ca}$ and phosphorus utilisation in broilers and laying hens. Hence, better understanding of variation in mineral analysis, particle size and solubility rate would enable more accurate feed inclusion and subsequently digestibility to support health and performance.
\end{abstract}

Keywords: calcium, limestone characteristics, phosphorus digestibility, phytase

\section{Introduction}

Calcium $(\mathrm{Ca})$ is an essential nutrient that is important for bone development and mineralisation, eggshell formation, muscle and neural functions (Klasing, 1998). Calcium metabolism is related to and influenced by the availability of phosphorus (P) and vitamin D (Proszkowiec-Weglarz and Angel, 2013) so that any inadequacy or excess of one may significantly affect the metabolism of the other. The utilisation of $\mathrm{Ca}$ and $\mathrm{P}$ depends on their concentration and availability in the feed and is modulated via intestinal, renal and skeletal mechanisms (Li et al., 2017). Ca digestibility is affected by phytase enzymes that are commonly added to poultry diets to improve the availability of phytate-bound $P$ and reduce unwanted excretion into the environment (Dersjant-Li et al., 2018; Selle and Ravindran, 2007). Phytase enzymes improve $\mathrm{Ca}$ availability by reducing the degree of phytate binding in the digestive tract, thereby increasing its availability for absorption and utilisation by the bird.

Ca requirements for poultry have historically been defined by the National Research Council (NRC, 1977), with various updates being published as data increased and the estimated nutrient requirements were refined (NRC, 1994). Additionally, other nutrient tables available from Centraal Veevoederbureau (CVB), Institut Nationale de la Recherche 
Agronomique (INRA) and Fundación Española para el Desarrollo de la Nutrición Animal (FEDNA) are available. Certain suppliers of poultry genetics have recommended specific ratios of $\mathrm{Ca}$ to available $\mathrm{P}$ in broiler (2:1) and layer (9:1 to 13:1) diets in order to ensure that these nutrients are in balance so that their metabolism and utilisation is optimised (Aviagen, 2019; Cobb, 2019; Joice and Hill Poultry, 2018). However, since poultry diets are still formulated using total $\mathrm{Ca}$, and multiple factors can contribute to differences in its utilisation, providing diets that deliver the correct ratio of digestible $\mathrm{Ca}: \mathrm{P}$ is not straightforward, and should ideally be based on knowledge of all factors that may influence availability in vivo. It has been reported that limestone in feed can contribute more than $50 \%$ of total dietary Ca consumed by broilers (Kim et al., 2019). For all-vegetable based broiler diets containing no meat or bone meal, this may increase to $70 \%$. In the case of layers, limestone can contribute more than $95 \%$ of $\mathrm{Ca}$ intake per hen per day. The remaining $\mathrm{Ca}$ comes from cereals, legumes and their by-products, bone meal, inorganic phosphates, monocalcium phosphate or di-calcium phosphate, premixes and feed additives. Walk (2016) showed that analysed $\mathrm{Ca}$ content in finished feed were, on average, $22 \%$ higher than the calculated content, and that calculated dietary $\mathrm{Ca}$ content could vary considerably, depending on the reference used for ingredient $\mathrm{Ca}$ concentration. This implied that relying on calculated values only may fail to provide an accurate estimate of dietary Ca content or its ratio to $\mathrm{P}$. Limestone variability can influence the analysed content of $\mathrm{Ca}$ in the final feed, although these factors are generally not considered in feed composition tables. For example, the Dutch feed tables (CVB, 2016) specify that the total Ca content of limestone is $38 \%$, whereas in a survey of 192 fine limestone samples, Plumstead et al. (2020) reported that the analysed Ca content ranged from 30.4 to $40.0 \%$. More recent literature has indicated that the Ca content of limestone can be as high as 42\% (Anwar et al., 2016; David et al., 2019; 2020). Interestingly, the maximum Ca content in pure $\mathrm{CaCO}_{3}$ is $40.04 \%$, based on chemical composition and molecular weight of $\mathrm{Ca}, \mathrm{C}$ and $\mathrm{O}$. Levels of $42 \%$ could be due to analytical errors or, in rare instances, where crushing of limestone generates heat that converts $\mathrm{CaCO}_{3}$ to $\mathrm{CaO}$, where the content would be higher.

Limestone particle size, chemical composition and rate of solubilisation may influence dietary Ca availability in vivo and need to be taken into account during diet formulation. However, there is limited research regarding differences among limestone sources, especially in regional and global samples. Limestone particle size is known to be related to its in vitro solubility (Zhang and Coon, 1997), but is altered by differences in the physical structure of the limestone rock and geological origin (Plumstead et al., 2020). Recent research has shown that limestone particle size and rate of solubility can affect $\mathrm{Ca}$ and $\mathrm{P}$ digestibility as well as phytase efficacy in complete feed (Davin et al.,
2020; Kim et al., 2018, 2019; Li et al., 2021). Knowledge in this area is still developing and a better understanding of the extent of variability in composition, particle size and solubility of limestone currently used in commercial feed production is required. Against this background, this study was undertaken to survey current limestone used in broiler and layer feed mills.

\section{Materials and methods}

\section{Limestone sample collection}

Limestone samples $(\mathrm{n}=566$ for fine limestone geometric mean diameter (GMD) $<1000 \mu \mathrm{m}$ ) were obtained from limestone sources that supply commercial feed mills situated in eight geographical regions: African countries (AF, $\mathrm{n}=11$, including Morocco, Malawi and other (nondescribed)); Australia and New Zealand (ANZ, $n=51$ ); Asia (India, Indonesia, Japan, Malaysia, Pakistan and Vietnam, $\mathrm{n}=25)$; European union including UK ( $\mathrm{EU}, \mathrm{n}=256$, including Belgium, Czech Republic, Denmark, Finland, France, Germany, Ireland, Italy, Norway, Poland, Portugal, Spain, Sweden, the Netherlands, Ukraine and United Kingdom); Middle East (ME, $n=23$, including Jordan, Saudi Arabia and Turkey); North America (NA, $\mathrm{n}=150$, including Canada, Costa Rica, Guatemala, Honduras, Nicaragua and USA); Russia (RU, $n=6$ ); South America (SA, $n=44$, including Argentina, Brazil and Colombia).

Additionally, total of 75 coarse limestone samples $(\mathrm{GMD}>1000 \mu \mathrm{m})$ were collected from the EU (including $\mathrm{UK})(\mathrm{n}=68), \mathrm{RU}(\mathrm{n}=3)$ and $\mathrm{ME}(\mathrm{n}=4)$.

\section{Limestone collection and analysis}

Limestone samples (500 g) were collected from commercial feed mills in each region and shipped to the laboratory (Chemunique Laboratory, Lanseria, South Africa). Upon arrival the samples were thoroughly mixed and halved using a Riffler sample splitter instrument (Lenton Laboratory and Scientific Equipment, Randburg, South Africa). One half was retained for repeat analysis if needed, and the other half (250 g) was analysed for mineral composition, particle size distribution and solubility.

Mineral analysis of limestone samples was done in duplicate using Inductively Coupled Plasma-optical Emission Spectroscopy (ICP-OES), according to the AOAC Method 985.01 (AOAC, 1996) to determine Ca, P, magnesium (Mg), iron $(\mathrm{Fe})$, manganese $(\mathrm{Mn})$, sodium $(\mathrm{Na})$, potassium $(\mathrm{K})$ and zinc $(\mathrm{Zn})$.

Particle size distribution was determined by sieving using a shaker and a set of 14 sieves, ranging from $25-3,350 \mu \mathrm{m}$, plus a base pan according to method ANSI/ASAE S319.4 (American Society of Agricultural and Biological Engineers, 
2008). The geometric diameter $(\mathrm{mm})$ of particles was calculated by mass, according to the equations described by Wilcox et al. (1962). Samples with a GMD $<1000 \mu \mathrm{m}$ were classed as 'fine', and those with a GMD $>1000 \mu \mathrm{m}$ as 'coarse'.

Historically, limestone solubility has been measured under acidic conditions $(0.2 \mathrm{~N} \mathrm{HCl})$ for 10 min using a method developed by Zhang and Coon (1997). However, this procedure was recently modified by Kim et al. (2019) using a $\mathrm{pH}$ more representative of conditions in the gizzard of chickens $(\mathrm{pH}=3.0$, produced by using $\mathrm{HCl}$ solution buffered with $3 \mathrm{M}$ glycine) and measured at three time points. The method of Kim et al. (2019) was used in this work. Briefly, the limestone solubility of $1 \mathrm{~g}$ from a representative sample of the limestone (for each time point) was measured at three incubation time points: 5,15 and $30 \mathrm{~min}$ for the fine limestone and at 30, 90 and $150 \mathrm{~min}$ for the coarse limestone.

\section{Statistical analysis}

Data were analysed to determine mean, standard error (SE), standard deviation (SD) and coefficient of variance (CV) by region. One-way ANOVA was used to determine statistical differences $(P<0.05)$ and Tukey's HSD was used to compare means. Pearson correlation coefficients $\left(R^{2}\right)$ were determined to evaluate the relationship between quantitative variables. Correlations between the content of $\mathrm{Ca}$ and of other minerals in limestone were assessed by application of a bivariate fit curve and calculation of the $R^{2}$ value, where correlations were statistically significant $(P<0.05)$. Correlations between limestone mean particle size and solubility were assessed by non-linear curve fitting. All data analyses were performed in the Fit Model platform of JMP 15.0 (SAS Institute Inc., Cary, NC, USA).

\section{Results and discussion}

\section{Limestone chemical composition}

The mineral contents including $\mathrm{Ca}$, copper $(\mathrm{Cu}), \mathrm{Fe}, \mathrm{K}$, $\mathrm{Mg}, \mathrm{Mn}, \mathrm{Na}, \mathrm{P}$ and $\mathrm{Zn}$ (percentage average) of the fine limestone was categorised by geographical region, and is presented in Figure 1 and Table 1 and 2.

Mean total Ca content of the 'fine' limestone was generally high, but was consistently below $40 \%$, with African (AF) counties having consistently lower averages (typically $<34 \%$ ). Ca content varied significantly across regions as well as within a region (as shown by minimum and maximum values in tables and figure). Mean Ca content varied by $6.4 \%$ among regions when $\mathrm{AF}$ was included, and $2.2 \%$ when $\mathrm{AF}$ was excluded. Mean Ca content was highest for samples from the Middle East (ME; 39.7\%). The number of samples

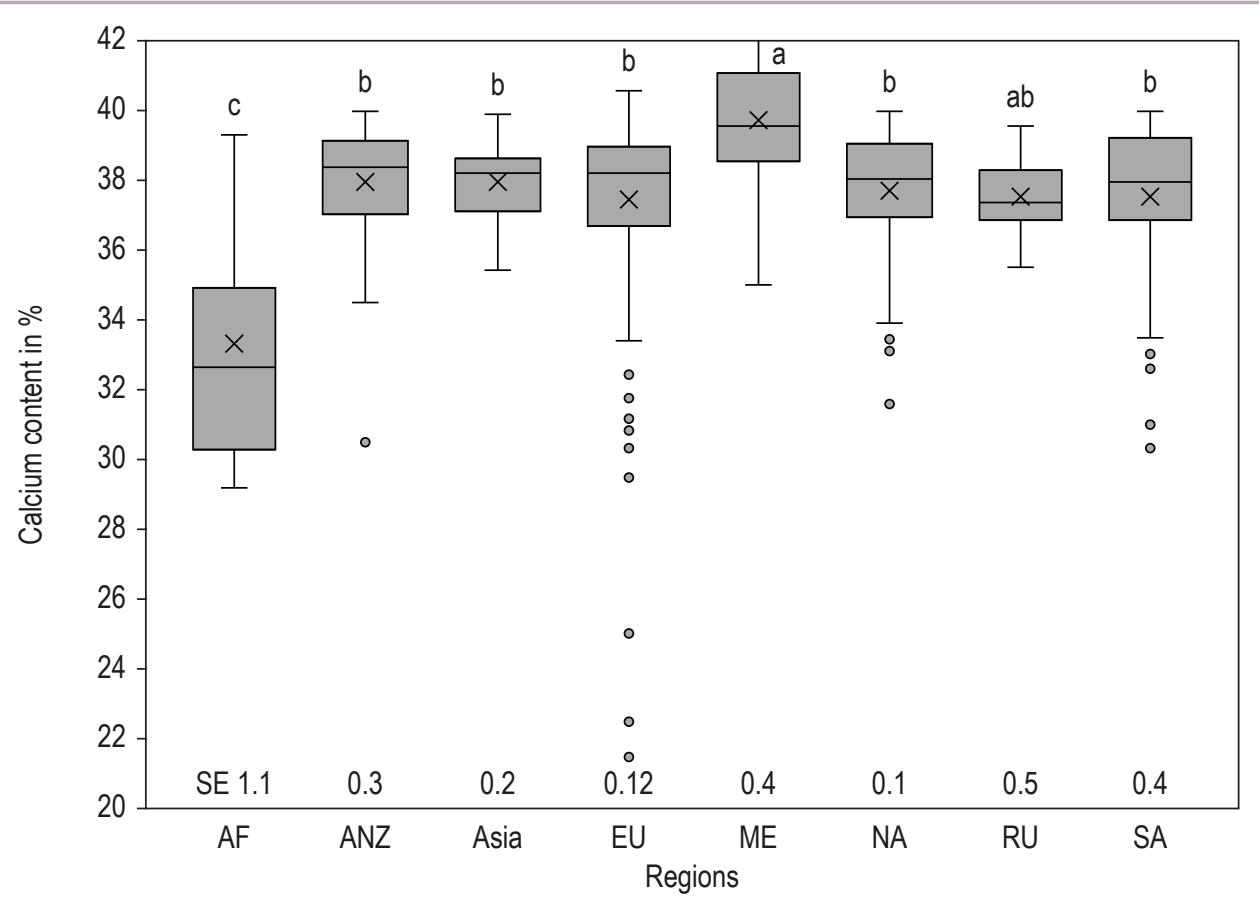

Figure 1. Calcium content in fine limestone from different global regions. Regions were defined as: AF = African countries Morocco, Malawi and other (non-described); ANZ = Australia and New Zealand; EU = European Union including UK (Belgium, Czech Republic, Denmark, Finland, France, Germany, Ireland, Italy, Norway, Poland, Portugal, Spain, Sweden, the Netherlands, Ukraine, United Kingdom; ME = Middle East Amman, Saudi Arabia and Turkey; NA = North America Canada, USA, Nicaragua, Honduras, Guatemala, Costa Rica; RU = Russia; SA = South America Argentina, Brazil, Columbia. SE = standard error. Different letters represent significant differences $(P<0.05)$. 
Table 1. Macromineral content (percent) of fine limestone (geometric mean diameter $<1000 \mathrm{~mm}$ ) samples by geographical region (total $\mathrm{n}=566)^{1}{ }^{1}$

\begin{tabular}{|c|c|c|c|c|c|c|c|c|c|c|c|c|c|c|c|c|c|}
\hline \multirow[t]{2}{*}{ Region ${ }^{2}$} & \multirow[t]{2}{*}{$\mathrm{n}$} & \multicolumn{4}{|c|}{ Magnesium \% } & \multicolumn{4}{|c|}{ Phosphorus \% } & \multicolumn{4}{|c|}{ Potassium \% } & \multicolumn{4}{|c|}{ Sodium \% } \\
\hline & & Mean & Min & Max & SE & Mean & Min & Max & SE & Mean & Min & Max & SE & Mean & Min & Max & SE \\
\hline AF & 11 & $1.56^{\mathrm{a}}$ & 0.08 & 6.25 & 0.62 & 0.02 & 0.01 & 0.05 & 0.00 & $0.02^{\mathrm{ab}}$ & 0.01 & 0.03 & 0.00 & 0.01 & 0.01 & 0.01 & 0.00 \\
\hline ANZ & 51 & $0.31^{b c}$ & 0.06 & 1.24 & 0.03 & 0.01 & 0.01 & 0.03 & 0.00 & $0.02^{b}$ & 0.01 & 0.12 & 0.00 & 0.01 & 0.01 & 0.04 & 0.00 \\
\hline Asia & 25 & $0.62^{b}$ & 0.01 & 2.33 & 0.14 & 0.02 & 0.01 & 0.08 & 0.00 & $0.02^{b}$ & 0.01 & 0.09 & 0.00 & 0.01 & 0.01 & 0.04 & 0.00 \\
\hline EU & 256 & $0.28^{c}$ & 0.02 & 2.86 & 0.02 & 0.22 & 0.01 & 34.71 & 0.15 & $0.06^{b}$ & 0.01 & 8.31 & 0.03 & 0.04 & 0.01 & 5.05 & 0.02 \\
\hline ME & 23 & $0.21^{\mathrm{c}}$ & 0.03 & 1.14 & 0.06 & 0.19 & 0.01 & 3.93 & 0.17 & $2.85^{\mathrm{a}}$ & 0.01 & 65.15 & 2.83 & 0.01 & 0.01 & 0.02 & 0.00 \\
\hline NA & 150 & $0.31^{c}$ & 0.07 & 2.21 & 0.02 & 0.03 & 0.01 & 0.72 & 0.01 & $0.02^{\mathrm{b}}$ & 0.01 & 0.22 & 0.00 & 0.03 & 0.01 & 0.51 & 0.00 \\
\hline $\mathrm{RU}$ & 6 & $0.45^{\mathrm{bc}}$ & 0.20 & 1.33 & 0.18 & 0.01 & 0.01 & 0.01 & 0.00 & $0.01^{\mathrm{ab}}$ & 0.01 & 0.02 & 0.00 & 0.01 & 0.01 & 0.02 & 0.00 \\
\hline SA & 44 & $0.39^{b c}$ & 0.02 & 2.55 & 0.08 & 0.03 & 0.01 & 0.12 & 0.00 & $0.02^{b}$ & 0.01 & 0.12 & 0.00 & 0.04 & 0.01 & 0.37 & 0.01 \\
\hline
\end{tabular}

${ }^{1}$ Superscripts with different values differ significantly $(P<0.05)$.

${ }^{2}$ Regions were defined as: AF = African countries Morocco, Malawi and other (non-described); ANZ = Australia and New Zealand; EU = European Union including UK (Belgium, Czech Republic, Denmark, Finland, France, Germany, Ireland, Italy, Norway, Poland, Portugal, Spain, Sweden, the Netherlands, Ukraine, United Kingdom; ME = Middle East Amman, Saudi Arabia and Turkey; NA = North America Canada, USA, Nicaragua, Honduras, Guatemala, Costa Rica; RU = Russia; $\mathrm{SA}=$ South America Argentina, Brazil, Columbia.

Table 2. Microminerals content $(\mathrm{mg} / \mathrm{kg}$ ) of fine limestone (geometric mean diameter $<1000 \mathrm{~mm}$ ) samples by geographical region (total $\mathrm{n}=566)^{1}$

\begin{tabular}{|c|c|c|c|c|c|c|c|c|c|c|c|c|c|c|c|c|c|}
\hline \multirow[t]{2}{*}{ Region ${ }^{2}$} & \multirow[t]{2}{*}{$\mathrm{n}$} & \multicolumn{4}{|c|}{ Copper mg/kg } & \multicolumn{4}{|c|}{ Iron mg/kg } & \multicolumn{4}{|c|}{ Manganese $\mathrm{mg} / \mathrm{kg}$} & \multicolumn{4}{|c|}{ Zinc $\mathrm{mg} / \mathrm{kg}$} \\
\hline & & Mean & Min & Max & SE & Mean & Min & Max & SE & Mean & Min & Max & SE & Mean & Min & Max & SE \\
\hline AF & 11 & $3.51^{\mathrm{ab}}$ & 0.01 & 10.00 & 1.30 & $4.463 .3^{a}$ & 120.69 & $26,897.30$ & $2,283.00$ & $625.4^{a}$ & 12.59 & $4,197.42$ & 364.41 & $11.79^{a b}$ & 2.06 & 18.03 & 1.31 \\
\hline ANZ & 51 & $3.58^{\mathrm{ab}}$ & 0.01 & 10.71 & 0.42 & $75.9^{b}$ & 62.52 & $6,241.57$ & 171.67 & $130.3^{b}$ & 0.01 & 598.93 & 19. & $51^{b}$ & 0.01 & 45.09 & 1.59 \\
\hline Asia & 25 & $2.47^{b}$ & 0.01 & 25.18 & 0.9 & $544.17^{b}$ & 124.80 & & & & 5.74 & & & $21.21^{\mathrm{ab}}$ & 0.01 & 161.75 & 6.57 \\
\hline EU & 256 & $3.33^{b}$ & 0.01 & 31.26 & 0.26 & $934.93^{b}$ & 42.66 & 8.325 .53 & 71.33 & $164.02^{\mathrm{b}}$ & 0.01 & 1.440 .34 & 13.93 & $19.84^{\mathrm{ab}}$ & 0.01 & 93.92 & 1.04 \\
\hline ME & 23 & $7.08^{\mathrm{a}}$ & 0.01 & 62.70 & 2.70 & $325.60^{\mathrm{b}}$ & 0.01 & $1,457.92$ & 90.15 & $67.37^{b}$ & 0.01 & 773.56 & 33.35 & $27.22^{\mathrm{a}}$ & 0.01 & 46.79 & 3.07 \\
\hline NA & 150 & $2.45^{b}$ & 0.01 & 39.58 & 0.40 & $817.57^{\mathrm{b}}$ & 143.64 & $5,246.49$ & 68.75 & $114.47^{\mathrm{b}}$ & 0.01 & $1,012.53$ & 11.79 & $26.10^{\mathrm{a}}$ & 0.01 & 239.00 & 2.52 \\
\hline $\mathrm{RU}$ & 6 & $2.93^{a b}$ & 0.70 & 7.52 & 1.10 & $1.761 .4^{\mathrm{b}}$ & 703.92 & 4.982 .76 & 654.01 & $163.77^{\mathrm{b}}$ & 30.70 & 345.44 & 50.81 & $14.24^{\mathrm{ab}}$ & 6.61 & 18.73 & 1.73 \\
\hline SA & 44 & $2.46^{\mathrm{b}}$ & 0.01 & 24.37 & 0.63 & $966.89^{b}$ & 0.01 & $7,680.44$ & 204.25 & $96.99^{b}$ & 0.01 & $1,724.43$ & 40.39 & $17.29^{a b}$ & 0.01 & 43.61 & 1.76 \\
\hline
\end{tabular}

${ }^{1}$ Superscripts with different values differ significantly $(P<0.05)$.

${ }^{2}$ Regions were defined as: AF = African countries Morocco, Malawi and other (non-described); ANZ = Australia and New Zealand; EU = European Union including UK (Belgium, Czech Republic, Denmark, Finland, France, Germany, Ireland, Italy, Norway, Poland, Portugal, Spain, Sweden, the Netherlands, Ukraine, United Kingdom; ME = Middle East Amman, Saudi Arabia and Turkey; NA = North America Canada, USA, Nicaragua, Honduras, Guatemala, Costa Rica; RU = Russia; SA = South America Argentina, Brazil, Columbia.

varied among regions which could explain some of the variation by region.

The analysed Ca content of limestone from different regions can be used to give an indication of the likely variation in dietary contribution. As an example, if a broiler grower diet was formulated to contain 1\% limestone using NRC (1994) feed tables on an analysed basis, limestone from AF would be expected to contribute $0.33 \%$ of $\mathrm{Ca}$ in the diet, instead of $0.38 \%$ based on the NRC feed table (NRC, 1994). Whilst the difference between these estimated contributions is relatively small, it would impact the actual content of $\mathrm{Ca}$ in the final diet. Furthermore, these estimates reflect the differences between region, not the total extent of variation between individual samples from different sources within the same region. This variation was considerably greater, as suggested by the range (minimum $29.2 \%$ for AF limestone, maximum $42.2 \%$ for ME). It was evident that the analysed Ca content of the limestone from different regions did not (with the exception of ANZ region) match the published value for limestone published by NRC (1994) of 38.0\%, although this value is frequently used by feed nutritionists as a basis for dietary formulation. The average $\mathrm{Ca}$ content of limestone samples from $\mathrm{AF}, \mathrm{EU}$ and $\mathrm{ME}$ regions were, respectively, $4.7 \%$ below, $0.3 \%$ below, and $1.7 \%$ above the NRC (1994) value, respectively.

Numerous in vivo studies have indicated that the analysed total Ca level in the diet can significantly alter growth performance outcomes, nutrient (Ca, $\mathrm{P}$ and phytate) digestibility and utilisation, and phytase efficacy (DersjantLi et al., 2018; Li et al., 2017; Powell et al., 2011; Tamim et al., 2004). Tamim et al. (2004) tested corn-soy diets containing no Ca compared with $0.5 \%$ Ca from limestone and reported a reduction in apparent ileal $\mathrm{Ca}$ (46.3 to $33.6 \%$ ) and $\mathrm{P}$ (67.9 to $29.4 \%$ ) absorption with increasing dietary Ca content. Studies by Kim et al. (2018) found no effect of increasing dietary Ca content from $0.6 \%$ to $1.0 \%$ 
on its apparent ileal digestibility (AID), however, AID of $\mathrm{P}$ decreased from $66.9 \%$ (0.6\% Ca) to $51.0 \%$ (1.0\% Ca) P when pulverised limestone was used as the Ca source $(75$ vs $402 \mu \mathrm{m})$. This suggested that total dietary $\mathrm{Ca}$ along with particle size can influence AID of both $\mathrm{Ca}$ and $\mathrm{P}$. The data for $\mathrm{Ca}$ content of limestone sources in Figure 1 and Table 3 suggested that analysis of limestone source prior to formulating is preferable to using estimated $\mathrm{Ca}$ content from feed composition tables. This would reduce uncertainty and improve accuracy in formulations for $\mathrm{Ca}$, reducing the likelihood of $\mathrm{Ca}$ being limiting or in excess.

There are few studies that can be used to compare with the current results. Anwar et al. (2017) reported $42 \% \mathrm{Ca}$ in fine $(<0.5 \mathrm{~mm})$ and coarse (1-2 mm) limestone sources from New Zealand ( $\mathrm{n}=2)$ and Wilkinson et al. (2013) reported $40.1 \%$ for fine ('powdered') limestone from Australia $(n=13)$. These values were slightly higher than the mean obtained for the ANZ region in the present study (38\%), which may reflect analytical errors or real differences in composition or a product of the small sample sizes employed in earlier studies. Both studies used a standard ICP-OES method for $\mathrm{Ca}$ determination, however inter-lab variation is known to exist. Davin et al. (2020) measured 38.2\% Ca in fine limestone $(<22 \mu \mathrm{m}, \mathrm{GMD})$ sourced from France and $37.4 \%$ for a coarse limestone $(564 \mu \mathrm{m}$, GMD) from Germany using ICP-OES. Pelicia et al. (2009) reported $35.7 \% \mathrm{Ca}$ for coarse (3.13 mm, GMD) and 36.5\% for fine $(0.18 \mathrm{~mm}, \mathrm{GMD})$ limestone, respectively, in a study in Brazil, which were somewhat lower than the average of $37.6 \%$ obtained for SA region in the present study. These limited comparisons supported the conclusion that there is considerable variation in Ca content of limestone within regions, between regions and across studies.

Other microminerals, such as $\mathrm{Mg}$ and $\mathrm{K}$, were present in the fine limestone at low levels relative to $\mathrm{Ca}$. However, AF region was significantly higher in $\mathrm{Mg}$ than other regions (Table 1). Similarly, EU and ME regional samples were lower in $\mathrm{Mg}$. Levels of $\mathrm{K}$ were significantly higher in $\mathrm{ME}$ samples compared to other regions. The micromineral content of the fine limestone varied among regions (Table 2) but did not appear to be related to $\mathrm{Ca}$. For example, total Ca was positively correlated with $\mathrm{Fe}\left(\mathrm{R}^{2}=0.21, P<0.001\right)$ and negatively correlated with $\mathrm{Mg}\left(\mathrm{R}^{2}=0.24, P<0.001\right)$. There appeared to be some region-specific differences in micromineral content, which may have been due to differences in local geology of the limestone rock. For example, $\mathrm{Cu}$ in limestone from ME were significantly higher than in EU and North America (NA) samples; Fe and Mn were significantly higher in AF samples compared than other regions, although there were only a small number of samples. Fe in samples from other regions differed numerically $(P>0.05)$. In contrast, Wilkinson et al. (2013) reported considerably lower Fe in samples from New Zealand than those reported currently for samples from the ANZ region (627 vs $1,075 \mathrm{mg} / \mathrm{kg}$ ), although contents of Mn (129 vs $130.3 \mathrm{mg} / \mathrm{kg})$ and $\mathrm{Zn}(7.2 \mathrm{vs} 10.5 \mathrm{mg} / \mathrm{kg})$ were comparable.

Coarse limestone (those with a GMD $>1000 \mu \mathrm{m}$ ) are typically used in layer diets, which are fed in mash form rather than as pellets. The chemical composition of the 'coarse' limestone samples is presented in Table 3. The data were not separated by region, because there were fewer samples in total $(n=75)$ and the majority were from one region, the $\mathrm{EU}(\mathrm{n}=68)$, with the remaining samples originating from Russia (RU, $n=3)$ and $M E(n=4)$.

The mean Ca content of coarse limestone was in the upper range of values seen for fine limestone, which may have been due to the smaller sample size and origin of the sample. Nevertheless, variation in the Ca content of coarse limestone was evident (minimum and maximum values differed by $>5 \%$; Table 3 ). Given that, in layer diets, limestone can contribute in excess of $90 \%$ of total dietary $\mathrm{Ca}$, such variation between individual coarse limestone types could significantly alter the total amount of $\mathrm{Ca}$ in the final diet if not taken into account during formulation.

The levels of microminerals in the coarse limestone showed substantial variability (Table 3 ), arguably greater than for the fine samples, with large CV (>90\%) even when SE values were comparatively small. For example, for potassium, the CV\% was 219.8 but the SE was only 0.01. Published data from other studies in coarse limestone are lacking, so no comparisons can be drawn. According to published work to date, limestone micromineral contents are not generally

Table 3. The chemical composition of coarse limestone (geometric mean diameter $>1000 \mu \mathrm{m}$ ) samples from all regions combined ( $\mathrm{n}=75$ ). ${ }^{1}$

\begin{tabular}{|c|c|c|c|c|c|c|c|c|c|}
\hline & $\begin{array}{l}\text { Calcium } \\
(\%)\end{array}$ & $\begin{array}{l}\text { Phosphorus } \\
(\%)\end{array}$ & $\begin{array}{l}\text { Magnesium } \\
(\%)\end{array}$ & $\begin{array}{l}\text { Copper } \\
\text { (mg/kg) }\end{array}$ & $\begin{array}{l}\text { Iron } \\
\text { (mg/kg) }\end{array}$ & $\begin{array}{l}\text { Manganese } \\
(\mathrm{mg} / \mathrm{kg})\end{array}$ & $\begin{array}{l}\text { Potassium } \\
(\%)\end{array}$ & $\begin{array}{l}\text { Sodium } \\
(\%)\end{array}$ & $\begin{array}{l}\text { Zinc } \\
\text { (mg/kg) }\end{array}$ \\
\hline Mean & 38.0 & 0.02 & 0.28 & 2.29 & 929.1 & 205.5 & 0.02 & 0.02 & 23.26 \\
\hline SD & 1.39 & 0.01 & 0.33 & 3.29 & 1,051 & 281.7 & 0.02 & 0.05 & 25.40 \\
\hline Min & 34.7 & 0.01 & 0.01 & 0.01 & 47.17 & 3.41 & 0.01 & 0.01 & 1.77 \\
\hline Max & 40.0 & 0.10 & 2.65 & 14.21 & 4,921 & 1,438 & 0.10 & 0.38 & 171.0 \\
\hline SE & 0.16 & 0.00 & 0.04 & 0.39 & 123.9 & 33.20 & 0.00 & 0.01 & 2.99 \\
\hline CV (\%) & 3.65 & 91.74 & 119.0 & 143.7 & 113.1 & 137.1 & 96.34 & 219.8 & 109.2 \\
\hline
\end{tabular}

${ }^{1} \mathrm{CV}=$ coefficient of variation; $\mathrm{SD}=$ standard deviation of the mean; SE = standard error. 
considered in diet formulation for poultry. The current data suggested that it may be beneficial to measure the micromineral contents on a regular basis to maintain levels in limits in finished feed. For example, Fe content ranged from 47.2 to $4,921 \mathrm{mg} / \mathrm{kg}$. At a limestone inclusion level of $8.6 \%$ in a layer diet, this would contribute up to $42 \mathrm{mg}$ $\mathrm{Fe} / \mathrm{kg}$ of feed (compared to laying hens' requirement of 40 $\mathrm{mg} / \mathrm{kg}$ of feed). It is important to mention that normally Fe is added in the premix to fulfil laying hens' requirements. Therefore, when selecting a limestone source, the purity and micromineral content should be considered.

\section{Limestone particle size}

The average GMD of the fine limestone samples (by region) and of the coarse limestone (all samples combined) is summarised in Table 4. Fine limestone exhibited considerable variation in particle size (GMD) both among, and especially within, geographic regions. Mean GMD was smallest in Asian samples (154 $\mu$ m GMD) which were significantly lower than NA samples, which had the greatest GMD at $356 \mu \mathrm{m}$, and were broadly comparable amongst most other regions. However, the mean GMD of individual limestone samples within the same region exhibited high variation, as evident from the large SD values which, in some cases, were only marginally lower than the mean itself, and from the CV values which were universally high (minimum $45.7 \%$ for RU limestone, maximum $91.9 \%$ for AF limestone). Coarse limestone (mean GMD 1,689 $\mu \mathrm{m}$ ) exhibited less variation in particle size among individual samples, as indicated by the lower CV\% and SD value compared with the fine samples. It is possible that variation may increase with more samples $(\mathrm{N})$ of coarse limestone.

In this survey, limestone samples were arbitrarily classified as 'fine' if they had a mean particle size (GMD) of $<1000$ $\mu \mathrm{m}$, or 'coarse' if they had a mean particle size (GMD) of $>1000 \mu \mathrm{m}$. These classifications are commonly used to differentiate limestone used in diets for broilers and laying hens, respectively. However, in practice, broiler diet formulations frequently use limestone with a particle size $<400 \mathrm{~mm}$ (GMD) because these feeds are generally pelleted. Smaller limestone particles result in less damage to feed pelleting equipment, minimises down time, and improves pellet quality.

\section{Limestone in vitro solubility}

The solubility of limestone in the fine limestone samples after 5, 15 and 30 minutes of incubation is shown by region in Figure 2A, 2B and 2C). The horizontal line in each box represents the median, symbol, $\mathrm{x}$ denotes to the mean value, the box limits around this mean represent the upper and lower percentile values either side of the mean, with the extremities of the vertical lines extending from each column represent the minimum and maximum values. Some outliers are shown as independent values. The average solubility of the limestone varied markedly even after only 5 min of incubation (Figure 2A), from as low as $56 \%$ for samples from AF region to as high as $83 \%$ for those from Asia and EU regions, with the percentile boundaries indicating a substantial amount of variation among individual samples around this mean value. Likewise, 5 min limestone solubility was significantly higher in samples from the EU compared to NA, SA and ANZ regions. Notwithstanding such individual variation, the rapid solubility of many of the fine samples was such that, in vivo, a large proportion of the $\mathrm{Ca}$ would be expected to have solubilised within the first 5 min of entering the proventriculus and gizzard. Such rapid solubilisation would result in a rise in $\mathrm{pH}$ due to the release of carbonate, while the rapid release of $\mathrm{Ca}$ cations can interact with phytate and other mineral cations, forming stable mineral-phytate complexes, which are less bioavailable and less accessible to phytase (Selle et al., 2000).

Table 4. Mean particle size of fine (geometric mean diameter $(G M D)<1000 \mu \mathrm{m}$ ) limestone by geographical region (total $n=566)$ and of coarse (GMD >1000 mm) limestone for all regions combined $(n=75) .^{1,2}$

\begin{tabular}{|c|c|c|c|c|c|c|c|c|}
\hline Limestone type & Region $^{3}$ & $\mathrm{n}$ & Mean GMD $(\mu \mathrm{m})$ & SD & $\operatorname{Min}(\boldsymbol{\mu m})$ & $\operatorname{Max}(\mu \mathrm{m})$ & SE & $\mathrm{CV}(\%)$ \\
\hline Coarse & $\begin{array}{l}\text { AF } \\
\text { ANZ } \\
\text { Asia } \\
\text { EU } \\
\text { ME } \\
\text { NA } \\
\text { RU } \\
\text { SA } \\
\text { P(ANOVA) } \\
\text { EU+RU+ME }\end{array}$ & $\begin{array}{c}11 \\
51 \\
25 \\
258 \\
23 \\
151 \\
6 \\
46 \\
0.0002 \\
75\end{array}$ & $\begin{array}{l}251.7^{a b} \\
275.7^{a b} \\
153.9^{b} \\
269.6^{b} \\
261.5^{a b} \\
356.3^{a} \\
234.9^{a b} \\
258.1^{a b}\end{array}$ & $\begin{array}{l}231.2 \\
200.1 \\
131.4 \\
234.3 \\
191.8 \\
196.6 \\
107.3 \\
194.4\end{array}$ & $\begin{array}{r}58.2 \\
47.6 \\
45.9 \\
38.5 \\
53.3 \\
37.7 \\
127.1 \\
49.0\end{array}$ & $\begin{array}{l}895.9 \\
902.9 \\
521.1 \\
988.2 \\
696.3 \\
992.0 \\
442.0 \\
951.8\end{array}$ & $\begin{array}{l}69.7 \\
28.0 \\
26.3 \\
14.6 \\
40.0 \\
16.0 \\
43.8 \\
28.7\end{array}$ & $\begin{array}{l}91.9 \\
72.6 \\
85.3 \\
86.9 \\
73.3 \\
55.2 \\
45.7 \\
68.2\end{array}$ \\
\hline
\end{tabular}

1 Superscripts with different values differ significantly $(P<0.05)$.

${ }^{2} \mathrm{CV}=$ coefficient of variation; $\mathrm{SD}=$ standard deviation of the mean; SE = standard error.

${ }^{3}$ Regions were defined as: AF = African countries Morocco, Malawi and other (non-described); ANZ = Australia and New Zealand; EU = European Union including UK (Belgium, Czech Republic, Denmark, Finland, France, Germany, Ireland, Italy, Norway, Poland, Portugal, Spain, Sweden, the Netherlands, Ukraine, United Kingdom; ME = Middle East Amman, Saudi Arabia and Turkey; NA = North America Canada, USA, Nicaragua, Honduras, Guatemala, Costa Rica; RU = Russia; $\mathrm{SA}=$ South America Argentina, Brazil, Columbia. 

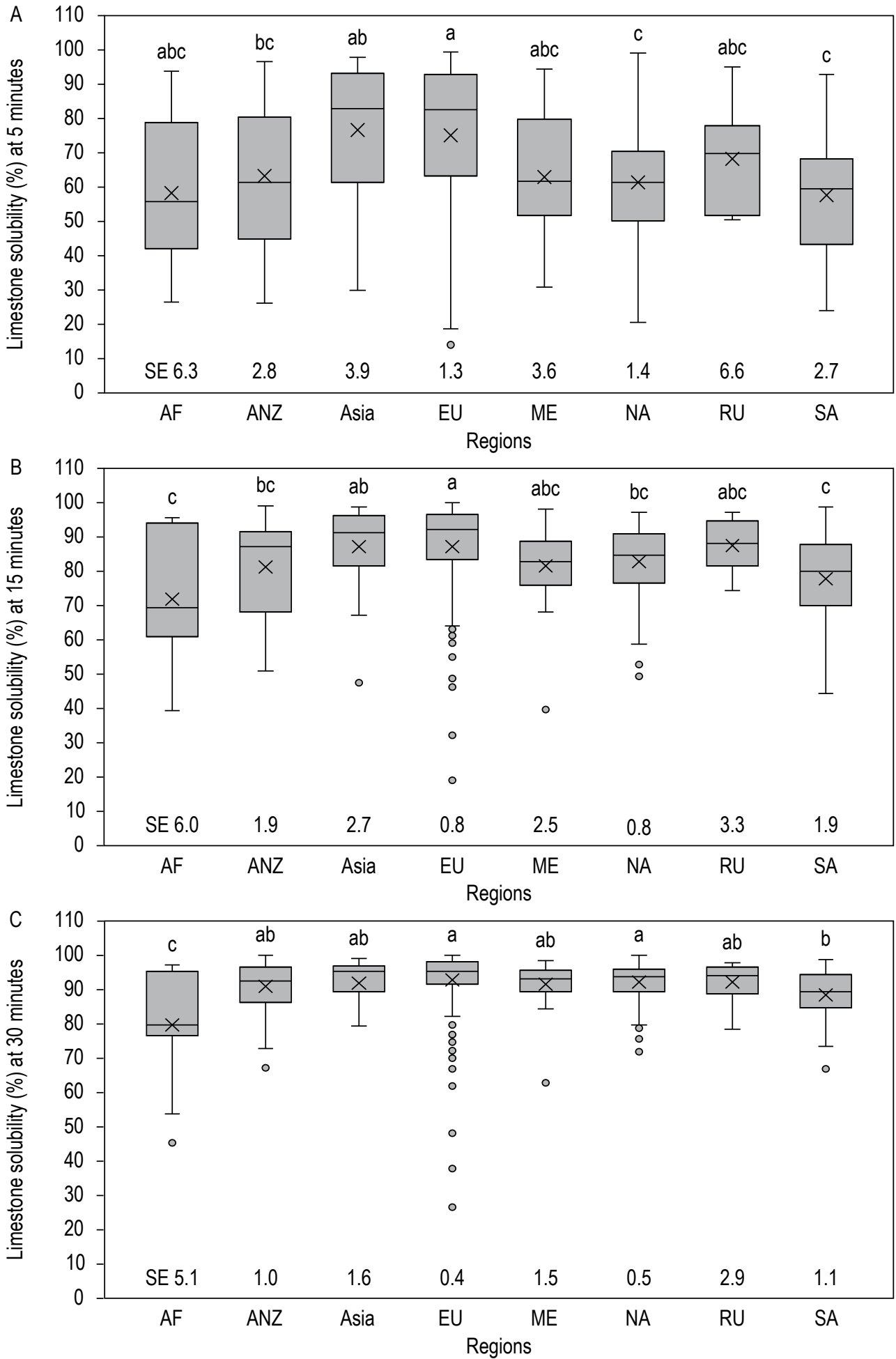

Figure 2. In vitro solubility of fine limestone ( $<1000 \mathrm{~mm}$ geometric mean diameter) after (A) $5 \mathrm{~min}$, (B) $15 \mathrm{~min}$ and (C) $30 \mathrm{~min}$ at pH=3.0, by geographical region ( $n=566$ ). Regions were defined as: AF = African countries Morocco, Malawi and other (non-described); ANZ = Australia and New Zealand; EU = European Union including UK (Belgium, Czech Republic, Denmark, Finland, France, Germany, Ireland, Italy, Norway, Poland, Portugal, Spain, Sweden, the Netherlands, Ukraine, United Kingdom; ME = Middle East Amman, Saudi Arabia and Turkey; NA = North America Canada, USA, Nicaragua, Honduras, Guatemala, Costa Rica; RU = Russia; SA = South America Argentina, Brazil, Columbia. Superscripts with different values differ significantly $(P<0.05)$. 
Thus, the wide variation in solubility of the samples both across, and especially within regions, would influence its bioavailability and potential to interact (beneficially or adversely) with other feed components.

After 15 min of incubation (Figure 2B), the mean solubility of fine limestone was further increased and by $30 \mathrm{~min}$ (Figure 2C) over $90 \%$ of the limestone had solubilised. The exception was the AF region (mean solubility after $30 \mathrm{~min}, 80 \%$ ), in which there was greater variation in the solubility of individual samples and a wider margin of error around the mean. This may have been due to the lower purity of limestone from AF, reflected by the lower $\mathrm{Ca}$ in limestone samples from the region. Similar to $5 \mathrm{~min}$ limestone solubility, 15 min solubilities for EU samples were significantly higher than ANZ, NA and SA regions but 30 min solubility was only significantly higher than AF and SA regions.

The solubility of coarse limestone after 30, 60 and $150 \mathrm{~min}$ of incubation is presented in Figure 3A, 3B and 3C. The small sample sizes from the $\mathrm{ME}$ and $\mathrm{RU}$ regions limited the interpretation of these results, but for the EU regional samples, mean solubility was $\sim 70 \%$ after $30 \mathrm{~min}, \sim 95 \%$ after $60 \mathrm{~min}$ and $>95 \%$ after $150 \mathrm{~min}$. As observed with fine limestone, there was considerable variation in among

A

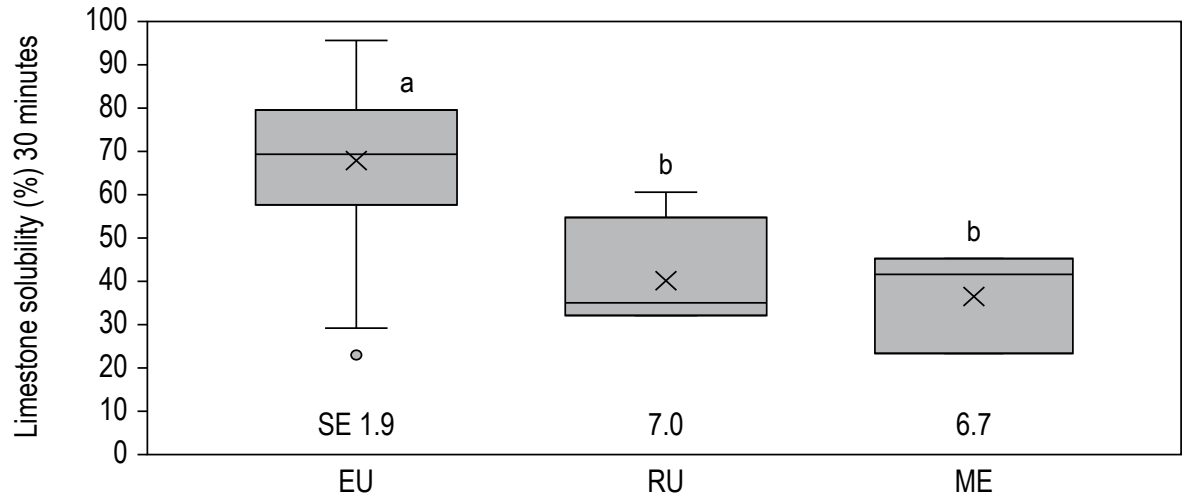

B

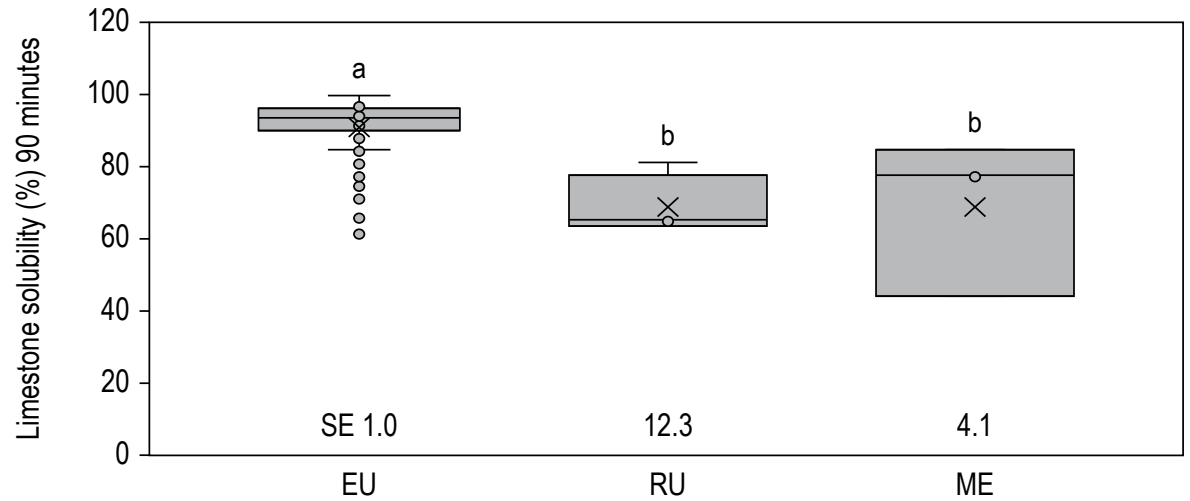

C

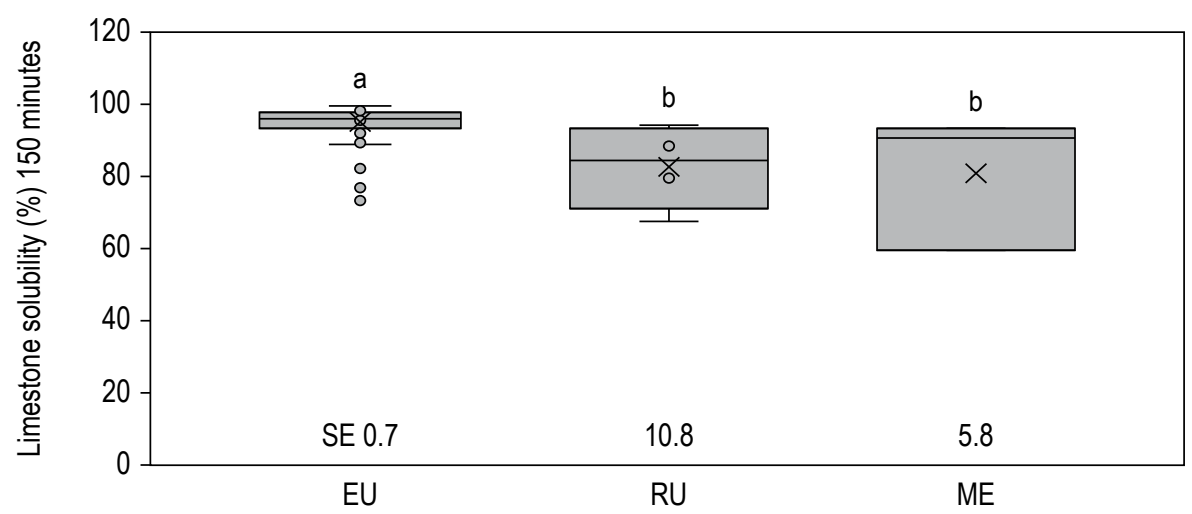

Figure 3. In vitro solubility of coarse limestone (>1000 $\mu \mathrm{m}$ geometric mean diameter) from the European Union (EU), Middle East (ME) and Russia (RU), after (A) $30 \mathrm{~min},(B) 90 \mathrm{~min}$ and (C) $150 \mathrm{~min}$ at $\mathrm{pH}=3.0(\mathrm{n}=75)$. 
individual coarse limestone from the EU at any given time point, but the shorter box plots in Figure 3, compared with Figure 2, suggested that the extent of this variability was less for coarse limestone.

Even though in vitro incubation attempted to mimic in vivo solubility in the proventriculus and gizzard $(\mathrm{pH}=3)$, how appropriate these assessments were is yet to be determined. The speed and extent of solubility in individual coarse or fine limestone samples in vivo have the capacity to influence $\mathrm{Ca}$ availability for absorption and to affect levels in the tissues which may impact on growth performance. Sinclair-Black (2019) recently observed that a coarse limestone $(1.5 \mathrm{~mm}$ GMD, 30\% solubility at $30 \mathrm{~min}$ ) increased blood ionisable Ca concentration in laying hens overnight, when more calcium is needed for eggshell formation, in comparison to a fine limestone $(0.2 \mathrm{~mm}$ GMD $86 \%$ solubility at 30 min). Zhang and Coon (1997) showed that limestone which was rapidly soluble in vitro (after $10 \mathrm{~min}$ incubation) were associated with reduced gizzard retention of limestone (after $72 \mathrm{~h}$ ) in vivo among laying hens, compared to limestone that are slower to solubilise, which could affect eggshell formation. However, their reported in vitro solubility was measured under highly acidic conditions, so the results were unlikely to be representative of in vivo solubility. In addition, more recent studies by the same authors reported that slowly soluble limestone was associated with increased bone strength and breaking force compared with rapidly soluble limestone in layer hens, when solubility was measured at pH 3 (i.e. conditions more representative of the proventriculus and gizzard; Zhang et al., 2017, 2020).
Correlation between limestone particle size and in vitro solubility

A few studies have demonstrated or suggested an inverse correlation between limestone particle size and solubility (Kim et al., 2018, Plumstead et al., 2020; Zhang and Coon, 1997), but it has been shown that different limestone sources with the same particle size can exhibit different solubilities (Plumstead et al., 2020; Zhang and Coon, 1997). In the present study, after 5,15 or 30 min of incubation, there was a weak negative correlation between mean particle size and in vitro solubility for fine limestone $\left(R^{2}=0.52,0.3\right.$ and 0.09 , respectively). However, for the coarse limestone there was no correlation between particle size and solubility at any of the incubation time points (30, 90 or $150 \mathrm{~min}$; $P>0.05)$. A few examples from some regions are shown in Figure 4, which shows that similar particle sizes of $322 \mu \mathrm{m}$ had 66 or $90 \%$ solubility at $5 \mathrm{~min}$ for the USA limestone samples. Likewise, samples from Brazil were almost $67 \%$ soluble at 5 min with contrasting 89 vs $435 \mu \mathrm{m}$ particle sizes. A similar trend was seen in samples from other regions, like Poland. Properties other than particle size must therefore influence limestone solubility, which could include quality and purity, its Ca content in relation to that of other macro and micronutrients or other substances present. In addition, the unique particle size distribution of the limestone source will vary from source to source. Finally, differences in the geological formation of the limestone may influence the rate of solubilisation. Ultimately, these findings suggested that particle size cannot be used alone as a reliable predictor for the in vitro or, by inference, in vivo solubility of limestone. Measurement of the solubility characteristics of the limestone prior to its use in dietary formulation would be preferable.

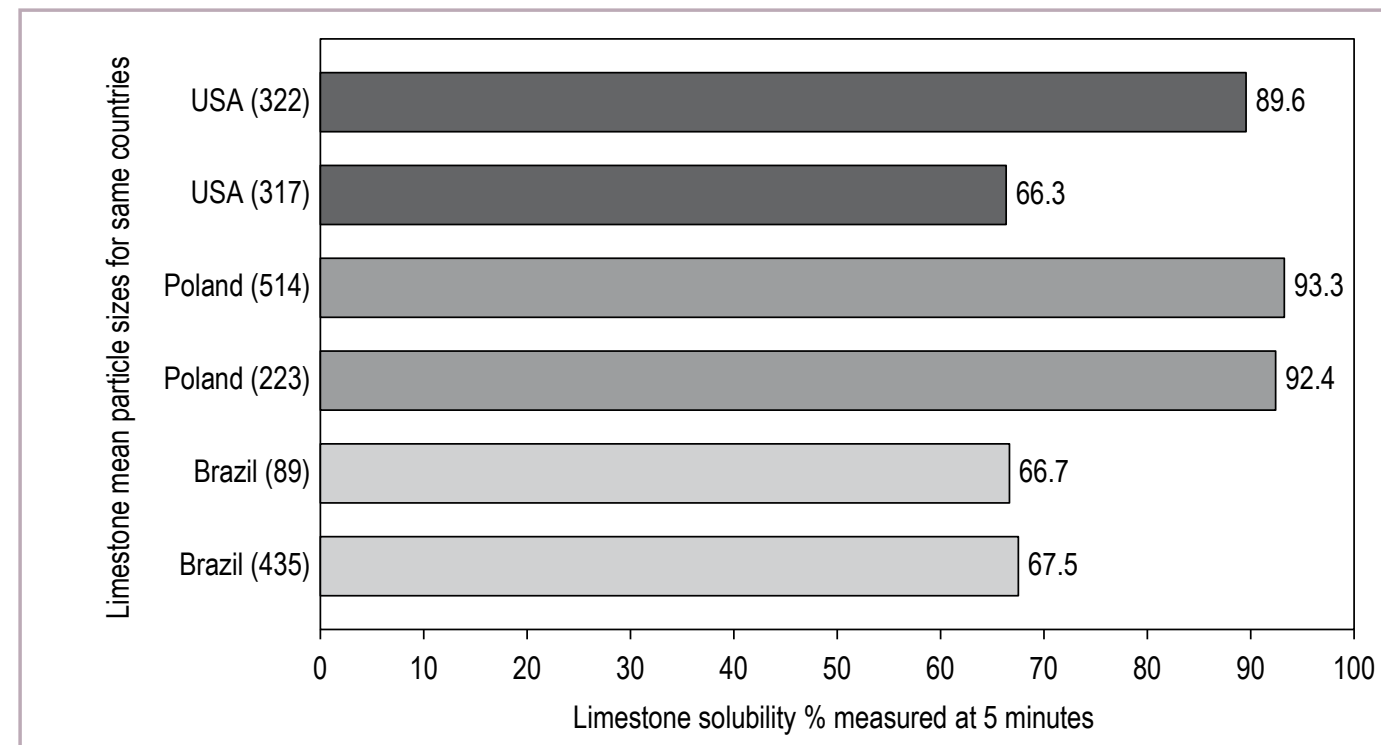

Figure 4. In vitro solubility of coarse limestone (>1000 mm geometric mean diameter) from the European Union (EU), Middle East (ME) and Russia (RU), after (A) $30 \mathrm{~min},(B) 90 \mathrm{~min}$ and (C) $150 \mathrm{~min}$ at $\mathrm{pH}=3.0(n=75)$. Means not sharing a letter differ significant $(P<0.05)$. 


\section{Practical implications of limestone solubility}

The variation at both global and regional level in the in vitro solubility of limestone sources supplied to commercial poultry feed mills was only partially explained by particle size (GMD), which was likely to impact on mineral digestibility in poultry which has the potential to affect growth performance and production. This was seen in the results from several recent studies in broilers, which showed negative relationships between in vitro solubility and in vivo digestibility of P. Some, but not all studies, observed effects of limestone solubility on ileal $\mathrm{Ca}$ and $\mathrm{P}$ digestibility in broilers. A selection of these studies is summarised in Table 5, based on the effects of particle size and solubility on $\mathrm{Ca}$ and $\mathrm{P}$ digestibility. It was difficult to compare all these studies, due to differences in methodology used to measure limestone solubility, age of birds and total $\mathrm{Ca}$ in the test diets. However, these studies indicated that, in the absence of phytase supplementation, the effect of limestone solubility and particle size on AID or standardised ileal digestibility (SID) of Ca was inconsistent between studies, whilst the effect on AID or SID of P appeared to be clearer and more reliable. Limestone with smaller particle size and higher solubility tended to reduce AID or SID of P (Table 5). Studies by Kim et al. (2018) and Davin et al. (2020) reported no effect of limestone particle size or solubility on AID Ca, independent of phytase addition. Kim et al. (2019) reported significant differences between limestone samples, and linear prediction models showed that GMD or solubility ( 5 min incubation) explained less than $40 \%$ and less than $25 \%$, respectively, of the variation in AID of Ca. Differences in geology and/or other physical or chemical characteristics presumably accounted for the rest of the variation. Li et al. (2021) reported that fine limestone produced a lower SID of Ca than coarse samples.

It is problematic to try to capture the effects of limestone particle size/solubility on mineral digestibility in the presence of phytase, but each of the studies in Table 5 provided useful data, which suggested that the characteristics of limestone that alter P digestibility also alter phytase efficacy in broiler diets. What is not yet well understood is whether the effects of limestone are similar for different phytase enzymes or different dose rates of phytase. Davin et al. (2020) observed that a slowly-soluble limestone with larger particle size $(\sim 10 \%$ solubility at $5 \mathrm{~min}, 564 \mu \mathrm{m}$

Table 5. Summary of in vivo studies that have investigated the effect of limestone particle size/solubility in complete feed on mineral digestibility in broilers. ${ }^{1}$

\begin{tabular}{|c|c|c|c|c|c|c|c|c|c|}
\hline \multirow[t]{2}{*}{ Publication } & \multirow{2}{*}{$\begin{array}{l}\text { Limestone source }{ }^{2} \\
\text { and particle size } \\
\text { (fine or coarse) }\end{array}$} & \multicolumn{3}{|c|}{$\begin{array}{l}\text { Limestone In vitro solubility } \\
\text { at } 5 \text { minutes duration }\end{array}$} & \multirow[t]{2}{*}{$\begin{array}{l}\text { Ca content } \\
(\%, \text { formulated })\end{array}$} & \multirow[t]{2}{*}{$\begin{array}{l}\text { Bird age } \\
\text { (d) }\end{array}$} & \multirow[t]{2}{*}{$\begin{array}{l}\text { AID Ca }{ }^{4} \\
(\%)\end{array}$} & \multirow[t]{2}{*}{$\begin{array}{l}\text { AID P4 } \\
(\%)\end{array}$} & \multirow[t]{2}{*}{$\begin{array}{l}\text { AID P (coars } \\
\text { vs fine })^{5}\end{array}$} \\
\hline & & $(\mathrm{GMD}, \mu \mathrm{m})$ & Method $^{3}$ & Solubility (\%) & & & & & \\
\hline \multirow[t]{6}{*}{ Kim et al., 2018} & $A-$ fine & 75 & 1 & 96.9 & 0.60 & 28 & 38.1 & 23.5 & \\
\hline & & & & & 0.80 & 28 & 47.3 & 20.5 & \\
\hline & & & & & 1.00 & 28 & 46.5 & 22.2 & \\
\hline & A-coarse & 402 & 1 & 74.3 & 0.60 & 28 & 44.8 & 31.5 & +8.0 \\
\hline & & & & & 0.80 & 28 & 50.8 & 27.9 & +7.4 \\
\hline & & & & & 1.00 & 28 & 42.9 & 25.3 & +3.1 \\
\hline \multirow[t]{4}{*}{ Kim et al., 2019} & $B-$ fine & 63 & 2 & 81.6 & 0.67 & 22 to 23 & 47.5 & 12.8 & \\
\hline & $C$ - coarse & 326 & 2 & 13.7 & 0.67 & 22 to 23 & 19.9 & 65.5 & +52.7 \\
\hline & B - coarse & 633 & 2 & 67.8 & 0.67 & 22 to 23 & 66.3 & 23.1 & +10.3 \\
\hline & D - coarse & 831 & 2 & 36.0 & 0.67 & 22 to 23 & 66.3 & 37.4 & +24.6 \\
\hline \multirow[t]{4}{*}{ Davin et al., 2020} & E - fine & $<20$ & 3 & $\sim 70.0^{6}$ & 0.76 (starter) & 21 & 37.7 & 48.3 & \\
\hline & & & & & 0.64 (grower) & & & & \\
\hline & $\mathrm{F}$ - coarse & 564 & 3 & $\sim 10.0^{6}$ & 0.76 (starter) & 21 & 39.4 & 52.4 & +4.1 \\
\hline & & & & & 0.64 (grower & & & & \\
\hline \multirow[t]{2}{*}{ Li et al., 2021} & $G-$ fine & 151 & 2 & 61.2 & 0.71 & 23 & 42.6 & 60.8 & \\
\hline & $G$ - coarse & 800 & 2 & 32.6 & 0.71 & 23 & 55.4 & 87.5 & +26.7 \\
\hline
\end{tabular}

${ }^{1} \mathrm{AID}=$ apparent ileal digestibility; GMD = geometric mean diameter.

${ }^{2}$ Limestone bearing the same letter were from the same source (within each study), whilst those bearing different letters were from different sources.

31 = modified weight loss method according to Zhang and Coon (1997); $0.2 \mathrm{~N} \mathrm{HCL}, \mathrm{pH}=0.7$, incubated at $42{ }^{\circ} \mathrm{C}$, post-filtered samples dried at $100{ }^{\circ} \mathrm{C}$ for $24 \mathrm{~h}$ and weighed to calculate weight loss. 2 = modified weight loss method according to Zhang and Coon (1997); pH $3.0 \mathrm{HCL}$ buffered with $3 \mathrm{M}$ glycine, incubated at $42^{\circ} \mathrm{C}$, post-filtered samples dried at $100^{\circ} \mathrm{C}$ for $>8 \mathrm{~h}$ and weighed to calculate weight loss. $3=$ in-house method; $1 \mathrm{M} \mathrm{HCL}$ added to $500 \mathrm{ml}$ water solution of limestone $(5.0 \mathrm{~g})$ at $40^{\circ} \mathrm{C}, \mathrm{pH}=3.0$.

${ }^{4}$ Values shown are for AID except for Li et al. (2021) where values are standardised ileal digestibility (SID).

${ }^{5}$ Percentage point difference between coarse and fine limestone.

${ }^{6}$ Approximate values obtained from Figure 1 in Davin et al. (2020). 
GMD) reduced AID Ca in treatments containing either of two phytase sources (Buttiauxella spp. or Escherichia coli phytase added at 500 or 1000 phytase units (FTU)/kg) when compared with a rapidly-soluble, finer limestone $(\sim 70 \%$ soluble at $5 \mathrm{~min},<20 \mu \mathrm{m}$ ). However, in the same study there was an interaction between limestone and phytase treatment, such that the improvement in AID Ca with phytase tended to be greater with the rapidly soluble, finer limestone. Meanwhile, Kim et al. $(2018,2019)$ and Li et al. (2021) observed no specific interactions between phytase and limestone on AID Ca. In terms of AID P, Kim et al. (2019) saw an interaction between phytase supplementation $(1000 \mathrm{FTU} / \mathrm{kg}$ ) and limestone type, so that effects of phytase on AID of P were not equal across all four limestone sources that differed in particle size. An earlier study by Kim et al. (2018) reported that AID of P in phytase supplemented treatments (1000 FTU/kg of a Buttiauxella spp. phytase) was affected by increasing the dietary Ca concentration only when fine limestone ( $75 \mu \mathrm{m}$ GMD) was used, but not when coarse limestone ( $402 \mu \mathrm{m}$ GMD) was used. These findings suggested that the influence of particle size and solubility on phytase efficacy in terms of $\mathrm{Ca}$ and $\mathrm{P}$ digestibility may vary for different limestone sources and may depend as well on other factors, such as dietary $\mathrm{Ca}$ and $\mathrm{P}$ content.

Davin et al. (2020) observed an interaction between limestone source (rapid vs slowly soluble) and phytase treatment on certain performance measures. Broiler bodyweight gain and feed intake during the grower and overall phases were reduced in rapid vs slowly soluble limestone supplemented with an E. coli phytase at 500 or $1000 \mathrm{FTU} / \mathrm{kg}$, but only in rapid vs slowly soluble limestone supplemented with a Buttiauxella spp. phytase at $500 \mathrm{FTU} / \mathrm{kg}$. At levels of $1000 \mathrm{FTU} / \mathrm{kg}$ of Buttiauxella spp. phytase, there was no longer any effect of solubility on performance. These findings suggested that, in order to mitigate the potential negative impact of limestone solubility on nutrient digestibility and growth performance, it may be necessary to increase phytase supplementation. In addition, the data implied that limestone solubility may be related to phytase source and enzymes that can break down phytate more rapidly in the upper GIT. This would, potentially reduce the formation of Ca-phytate complexes and mitigate the impact of rapidly soluble limestone.

\section{Conclusion}

This survey of limestone highlighted the extent of variation that currently exists in macro and micromineral content, particle size and in vitro solubility. All of these characteristics are important factors in understanding and predicting the availability of $\mathrm{Ca}$ from limestone in diets and its effect on $\mathrm{P}$ utilisation and phytase efficacy in vivo. The extent of variation in Ca content in both fine $(<1000 \mu \mathrm{m}$ GMD) and coarse ( $>1000 \mu \mathrm{m}$ GMD) limestone suggested that the use of estimates of limestone Ca content from published feed tables is not sufficient for accurate dietary formulation of $\mathrm{Ca}$. Whilst broiler diets are currently often formulated with excess $\mathrm{Ca}$ and $\mathrm{P}$ in order to ensure that mineral requirements are met, high ingredient costs and sustainability considerations mean that there is a move towards diets closer to requirement levels and on a leastcost basis. Under this scenario, variations in limestone quality that may affect the $\mathrm{Ca}$ and $\mathrm{P}$ availability in the final diet and interactions with other feed components, such as phytase in the digestive tract, may become more important.

\section{Acknowledgements}

The authors would like to thank Dr Joelle Buck (Newbury, UK) for her assistance with the editing of this manuscript and the laboratory at Chemunique' Pty Ltd for conducting the in vitro analysis of limestone samples.

\section{Conflict of interest}

Limestone analysis was funded by Danisco Animal Nutrition (IFF)

\section{References}

American Society of Agricultural and Biological Engineers, 2008. Method of determining and expressing fineness of feed materials by sieving (ANSI/ASAE S319.4). ASABE, St. Joseph, MI, USA.

Anwar, M.N., Ravindran, V., Morel, P.C.H., Ravindran, G. and Cowieson, A.J., 2016. Effect of limestone particle size and calcium to non-phytate phosphorus ratio on true ileal calcium digestibility of limestone for broiler chickens. British Poultry Science 57: 707713. https://doi.org/10.1080/00071668.2016.1196341

Anwar, M.N., Ravindran, V., Morel, P.C.H., Ravindran, G. and Cowieson, A.J., 2017. Effect of calcium source and particle size on the true ileal digestibility and total tract retention of calcium in broiler chickens. Animal Feed Science and Technology 224: 39-45. https://doi.org/10.1016/j.anifeedsci.2016.12.002

Association of Analytical Chemists (AOAC), 1996. AOAC Official Method 985.01-1988(1996). Metals and other elements in plants and pet foods. Inductively coupled plasma (ICP) spectroscopic method. AOAC, Rockville, MD, USA. Available at: https://tinyurl. com/2p8aara9

Aviagen, 2019. Ross 308 broiler: nutrition specifications. Available at: https://tinyurl.com/2p8353hp

Cobb, 2019. Cobb 500 broiler performance and nutrition supplement. Available at: https://tinyurl.com/msw8v36j

CVB, 2016. Feeding standards and nutritional values of feeding ingredients for poultry. Federatie Nederlandse Diervoederketen, Wageningen, the Netherlands.

David, L.S., Abdollahi, M.R., Bedford, M.R. and Ravindran, V., 2020. True ileal calcium digestibility in soybean meal and canola meal, and true ileal phosphorous digestibility in maize-soybean meal and maize-canola meal diets, without and with microbial phytase, for broiler growers and finishers. British Poultry Science 62(2): 293-303. https://doi.org/10.1080/00071668.2020.1849559 
David, L.S., Abdollahi, M.R., Ravindran, G., Walk, C.L. and Ravindran, V., 2019. Studies on the measurement of ileal calcium digestibility of calcium sources in broiler chickens. Poultry Science 98: 5582-5589. https://doi.org/10.3382/ps/pez314

Davin, R., Kwakernaak, C. and Derskant-Li, Y., 2020. Effect of commercial limestone sources with different solubility on the efficacy of two phytases in 0-21 d old broilers. Journal of Applied Animal Nutrition 8: 61-73. https://doi.org/10.3920/JAAN2020.0003

Dersjant-Li, Y., Evans, C. and Kumar, A., 2018. Effect of phytase dose and reduction in dietary calcium on performance, nutrient digestibility, bone ash and mineralisation in broilers fed cornsoybean meal-based diets with reduced nutrient density. Animal Feed Science and Technology 242: 95-110.

Joice and Hill Poultry, 2018. ISA brown management guide. Joice and Hill Poultry, Peterborough, UK. Available at: https://tinyurl. com/3e4y2jvw

Kim, S.-W., Li, W., Angel, R. and Proszkowiec-Weglarz, M., 2018. Effects of limestone particle size and dietary Ca concentration on apparent $\mathrm{P}$ and Ca digestibility in the presence or absence of phytase. Poultry Science 97: 4306-4314. https://doi.org/10.3382/ps/pey304

Kim, S-W., Li, W., Angel, R., Plumstead, P.W., 2019. Modification of a limestone solubility method and potential to correlate with in vivo limestone calcium digestibility. Poultry Science 98: 6837-6848. https://doi.org/10.3382/ps/pez423

Klasing, K., 1998. Comparative avian nutrition. CAB International, Wallingford, UK, $352 \mathrm{pp}$.

Li, W., Angel, R., Plumstead, P.W. and Enting, H., 2021. Effects of limestone particle size, phytate, calcium source, and phytase on standardized ileal calcium and phosphorus digestibility in broilers. Poultry Science 100: 900-909. https://doi.org/10.1016/j. psj.2020.10.075

Li, X., Zhang, D. and Bryden, W.L., 2017. Calcium and phosphorus metabolism and nutrition in poultry: are current diets formulated in excess? Animal Production Science 57: 2304-2310. https://doi. org/10.1071/an17389

National Research Council (NRC), 1977. Nutrient requirements of poultry, $7^{\text {th }}$ edition. National Academy Press, Washington, DC, USA.

National Research Council (NRC), 1994. Nutrient requirements of poultry, $9^{\text {th }}$ edition. National Academy Press, Washington, DC, USA.

Pelicia, K., Garcia, E., Móri, C., Faitarone, A.B.G., Silva, A.P., Molino, A.B. and Berto, D.A., 2009. Calcium levels and limestone particle size in the diet of commercial layers at the end of the first production cycle. Brazilian Journal of Poultry Science 11: 87-94. https://doi. org/10.1590/S1516-635X2009000200003

Plumstead, P.W., Sinclair-Black, M. and Angel, C.R., 2020. The benefits of measuring calcium digestibility from raw materials in broilers, meat breeders, and layers. Proceedings of the Australian Poultry Science Symposium 31: 24-31.
Powell, S., Bidner, T.D. and Southern, L.L., 2011. Phytase supplementation improved growth performance and bone characteristics in broilers fed varying level of dietary calcium. Poultry Science 90: 604-608. https://doi.org/10.3382/ps.2010-01000

Proszkowiec-Weglarz, M. and Angel, R., 2013. Calcium and phosphorus metabolism in broilers: effect of homeostatic mechanism on calcium and phosphorus digestibility. Journal of Applied. Poultry Research 22: 609-627. https://doi.org/10.3382/japr.2012-00743

Selle, P.H. and Ravindran, V., 2007. Microbial phytase in poultry nutrition. Animal Feed Science and Technology 135: 1-41.

Selle, P.H., Ravindran, V., Caldwell, R.A. and Bryden, W.L., 2000. Phytate and phytase: consequences for protein utilisation. Nutrition Research Reviews 13: 255-278. https://doi.org/10.1079/095442200108729098

Sinclair-Black, M., Angel, R., Li, W. and Plumstead, P., 2019. The effect of limestone particle size, phytase inclusion, and time post oviposition on ionized blood calcium levels in commercial laying hens. Proceedings of the $22^{\text {nd }}$ European Symposium on Poultry Nutrition. June 10-13, 2019. Gdańsk, Poland. Available at: https:// tinyurl.com/yckrcfrp

Tamim, N.M., Angel, R. and Christman, M., 2004. Influence of dietary calcium and phytase on phytate phosphorus hydrolysis in broiler chickens. Poultry Science 83: 1358-1367.

Walk, C.L., 2016. The influence of calcium on phytase efficacy in non-ruminant animals. Animal Production Science 56: 1345-1349. https://doi.org/10.1071/an15341

Wilcox, R., Deyoe, C. and Pfost, H.B., 1962. A method for determining and expressing the size of feed particles by sieving. Poultry Science 49: 9-13.

Wilkinson, S.J., Ruth, B. and Cowieson, A.J., 2013. Mineral composition of calcium sources used by the Australian poultry feed industry. Proceedings of the Australian Poultry Science Symposium 24: 45-48.

Zhang, B. and Coon, C.N., 1997. The relationship of calcium intake, source, size, solubility in vitro and in vivo, and gizzard limestone retention in laying hens. Poultry Science 76: 1702-1706. https:// doi.org/10.1093/ps/76.12.1702

Zhang, B., Caldas, J.V. and Coon, C.N., 2017. Effect of dietary calcium intake and limestone solubility on egg shell quality and bone parameters for aged laying hens. International Journal of Poultry Science 16: 132-138. https://doi.org/10.3923/ijps.2017.132.138

Zhang, B., Weil, J., Guerra, A.B., Maharjan, P., Hilton, K., Suesuttajit, N., Patr, D.M.P. and Coon, C.N., 2020. Egg shell quality and bone status as affected by environmental temperature, $\mathrm{Ca}$ and nonphytate P intake and in vitro limestone solubility in Single-Comb White Leghorn hens. International Journal of Poultry Science 19: 219-231. https://doi.org/10.3923/ijps.2020.219.231 